\title{
Jesuit Winemaking and Art Production in Northern New Spain
}

\author{
Katherine Moore McAllen \\ University of Texas Rio Grande Valley \\ Katherine.mcallen@utrgv.edu
}

\begin{abstract}
This article presents new research on Jesuit visual culture in northern New Spain, situating Santa María de las Parras (founded 1598) as an important site where the Jesuits and secular landowners became involved in the lucrative business of winemaking. Viticulture in Parras helped transform this mission settlement into a thriving center of consumption. The Jesuits fostered alliances with Spanish and Tlaxcalan Indians to serve their religious and temporal interests, as these patrons donated funds to decorate chapels in the Jesuit church of San Ignacio. This financial support allowed the Society to purchase paintings by prominent artists in Mexico City and import them to Parras. The Jesuits arranged their chapels in a carefully ordered sequencing of images that promoted Ignatian spirituality and echoed iconographic decoration programs in Mexico City and Rome.
\end{abstract}

\section{Keywords}

Jesuit art and architecture - Northern New Spain - colonial Mexico - viticulture Tlaxcalan Indians - patronage - Santa María de las Parras

Between the late sixteenth and the eighteenth centuries, the Jesuits and Franciscans founded their missions along the northern border regions of the Spanish viceroyalty of New Spain, which today comprises Mexico and portions of the American Southwest. The focus of these religious orders was to promote evangelization and protect the physical boundaries of the empire. Members of the Society of Jesus also established economic enterprises that played a key role in the Jesuits' and the Spanish crown's successful expansion into northeastern

(C) KATHERINE MOORE MCALLEN, 2019 | DOI:10.1163/22141332-00602006

This is an open access article distributed under the terms of the prevailing CC-BY-NC license at the time of publication. 
New Spain. The Jesuits became involved after 1598 in the lucrative business of winemaking in Santa María de las Parras, where viticulture helped transform this mission settlement into a thriving town and center for importing art. In the first decades of the seventeenth century, the Jesuits constructed the mission church of San Ignacio de Loyola, which was transformed in 1640 to a church within an inchoate college complex. The Jesuits fostered alliances with both Spanish and Tlaxcalan Indian families, who became leading patrons and funded the construction and adornment of this Jesuit church. This essay will examine how the financial support of vineyard owners in Parras played a role in the Jesuits' selection of artworks for San Ignacio de Loyola, which were arranged in a carefully ordered sequencing of images that appealed to patrons' devotions and promoted Ignatian spirituality.

The Jesuits cultivated their economic as well as spiritual interests almost immediately upon arriving in New Spain and Peru in the sixteenth century. The rental of properties and operation of haciendas enabled the order to ensure the success of their evangelization and education efforts that began in urban settings such as Mexico City and expanded into winemaking and ranching investments on viceregal frontiers. ${ }^{1}$ The first Jesuits arrived in Mexico City in 1572 after Superior General Francisco de Borja (in office 1565-72) answered the requests of the viceroy and other colonial officials and bishops, including Vasco de Quiroga in Michoacán (in office 1538-65), to send the Society of Jesus from Rome to New Spain. In contrast to the Franciscans' legendary arrival into Tenochtitlan fifty years earlier as "The Twelve," the Jesuits entered the viceregal capital discreetly in the night. ${ }^{2}$ While projecting this low profile on one hand, the order promptly received large monetary donations and began acquiring agricultural estates offered by prominent patrons in the viceregal

1 This article is dedicated to James, James III, Salomé, and Georgiana, for their support at all times, as well as to Tom Cummins, Clara Bargellini, Susan Deans-Smith, Luisa Elena Alcalá, and Jeffrey Chipps Smith, who have been inspiring advisors and colleagues. I also extend my thanks to editor Alison Fleming for her diligent dedication to this project. The Jesuits received substantial revenues on both American continents from their ownership of haciendas, ranches, and vineyards. See, for example, Sergio Antonio Corona Páez, Viñedos y vendimias en la Nueva Vizcaya (Torreón: Universidad Iberoamericana, 2003); Nicholas Cushner, Lords of the Land: Sugar, Wine, and Jesuit Estates of Coastal Peru (Albany: University of New York Press, 1980); Cushner, Jesuit Ranches and the Agrarian Development of Colonial Argentina, 1650-1767 (Albany: State University of New York Press, 1983).

2 Lorenza Autrey Maza and Rafael Rodríguez Castañeda, La Profesa: Patrimonio artístico y cultural (Mexico City: Secretaría de Desarrollo Urbano y Ecología, 1988), 11. 
capital between 1573 and $1585 .{ }^{3}$ The Jesuits spent nearly twenty years in Mexico City before expanding their presence north of the viceregal capital to establish their mission of San Luis de la Paz in 1588 in present-day Guanajuato.

By the eighteenth century, hundreds of Jesuit missions occupied the northern regions of the viceroyalty along with other orders such as the Franciscans. As a 1754 map of New Spain engraved by Joannes Petroschi depicts, the Jesuits reformulated the boundaries of their Mexican province in New Spain in the mid-eighteenth century to include a vice province in the north to organize their growing mission system (Figure 6.1). Parras, which once was part of the northern frontier, was included in the main province of the Society. As it grew and transformed, Parras embodied the transformative nature of the New Spanish frontier that existed not as a single place but as multiple, permeable "zones

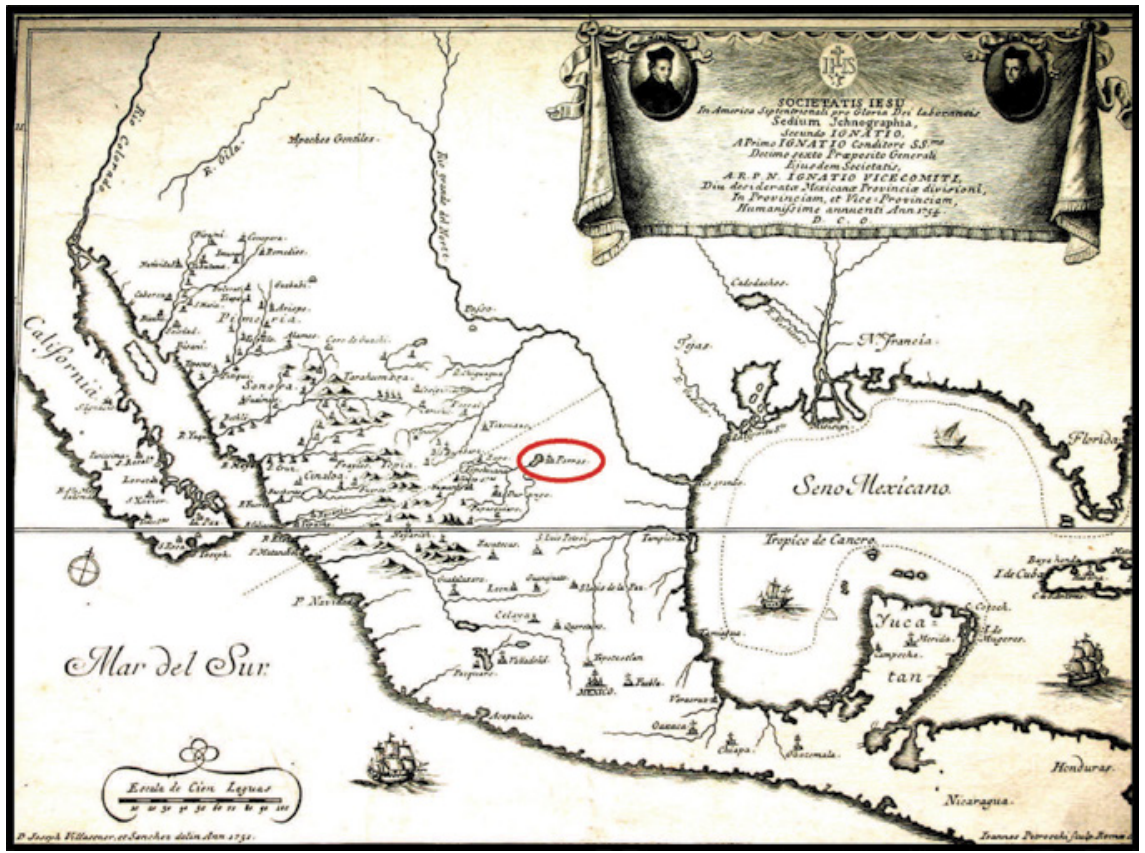

FIGURE 6.1 Joannes Petroschi, Map of the Jesuit Province and Vice-Province of New Spain. Rome, 1754

ARCHIVUM ROMANUM SOCIETATIS IESU, ROME

3 See the classic study by Herman Konrad, A Jesuit Hacienda in Colonial Mexico: Santa Lucía, 1576-1767 (Stanford: Stanford University Press, 1980), 16; Juan Sánchez Baquero, Fundación de la Compañía de Jesús en la Nueva España, 1571-8o (Mexico City: Editorial Patria, 1945), 48-50. 
of interaction" that were always historically changing. ${ }^{4}$ Located in eastern Nueva Vizcaya, Santa María de las Parras was founded as both a Spanish pueblo (town) and a Jesuit mission in 1598 in the fertile river basin surrounded by the Sierra Madre Oriental mountains. The modern town of Parras de la Fuente is today located between the cities of Torreón to the west and Saltillo to the east in the southern region of the state of Coahuila, Mexico. Parras became the Society's easternmost mission in northern New Spain after the Franciscans abandoned their settlement in this location. This region in northeastern New Spain was dominated by Franciscan missions nearby in Saltillo and further east in Nuevo León and Texas. Parras was therefore uniquely positioned within a contested space. ${ }^{5}$ While negotiating their own mission boundaries by establishing their presence in Parras, the Jesuits also actively cultivated relationships with secular patrons to acquire land and water sources for winemaking enterprises. The financial support of these benefactors helped the Jesuits begin a campaign over the next century and a half to fund the production and transport of artworks from Mexico City to Parras.

The majority of the documents recording how the Jesuits created a sophisticated decoration program in their church of San Ignacio de Loyola are located in the Archivo General de la Nación in Mexico City, the Archivo Histórico de la Provincia de México de la Compañía de Jesús in Mexico City, as well as the Archivo Histórico del Colegio de San Ignacio de Loyola de Loyola de Parras,

4 Cynthia Radding uses this term as well as "corridors of exchange" in her comparative studies of multiple borderlands evolving on the frontiers of colonial America in Landscapes of Power and Identity: Comparative Histories in the Sonoran Desert and the Forests of Amazonia from Colony to Republic (Durham: Duke University Press, 2005), 8. David Weber uses the term "zones of interaction" when discussing the dynamic nature of the colonial frontier in North America in The Spanish Frontier in North America (New Haven: Yale University Press, 1992), 11. For the changing nature of colonial frontiers, see John Jay TePaske, "Integral to Empire: The Vital Peripheries of Colonial Spanish America," in Negotiated Empires: Centers and Peripheries in the Americas, 1500-1820, ed. Christine Daniels and Michael Kennedy (New York: Routledge, 2002), 29-43, here 30.

5 The Jesuits acknowledged that in the late 1580 s the Franciscans established a mission in Parras identified as el Valle de los Pirineos that the friars abandoned before moving north to New Mexico with Juan de Oñate's expedition in the 159os. See Biblioteca Nacional, Mexico City, Fondo Archivo Franciscano [hereafter BNFAF], Legajos AF 16/326, fols. 1-11, AF 11/171, fols. $4^{\mathrm{r}}-5^{\mathrm{v}}, 14^{\mathrm{r}}, \mathrm{AF} 17 / 344$ fols. $1-26^{\mathrm{v}}$. For more on the competition within the orders, see Charles W. Polzer, S.J., "The Franciscan entrada into Sonora 1645-1652: A Jesuit Chronicle," Arizona and the West 14 (1972): 253-78, here 255 . 
which is located at the Jesuit Universidad Iberoamericana Laguna in Torreón, Mexico. Financial records related to the Jesuits' income from winemaking and agricultural enterprises at Parras and other missions, residences, and colleges throughout New Spain are located in Madrid in the Archivo Histórico Nacional and in Rome in the Archivum Romanum Societatis Iesu. Parras presents a unique case study to examine how winemaking funded the Jesuits' art production in their church of San Ignacio de Loyola in northern New Spain, because many of the artworks survive today and can be connected to their original patrons, who were economic supporters of the Jesuits.

In 1598 , the Jesuits founded their mission in strategic proximity to the existing vineyards of future patrons Lorenzo García (d.1630) and Francisco de Urdiñola (d.1618), the first Marques de San Miguel de Aguayo. These early colonizers, who would later support Jesuit church decoration projects, received the first Spanish land grants to produce wine in Parras. ${ }^{6}$ The ideal climate, soil quality, and abundant water sources fed by the floodwaters of the Río de las Nasas, which was known in the north as "the Mexican Nile," provided the perfect conditions for growing grapevines. In return for their role in founding the mission in 1598, the crown gave the Jesuits and Spanish and Tlaxcalan vineyard owners substantial ownership of the water sources in Parras. This water, shown with dark lines in the c.1670 map of Parras, flowed through irrigated canals into the town and to surrounding vineyards (Figure 6.2). These water sources enabled winemaking to flourish and become the economic base of the community in this fertile river basin. By becoming involved in these lucrative viticulture enterprises, the Jesuits played an important role in transforming this peripheral mission settlement into an important wine production center. By 1767 , three million vines were documented in Parras. ${ }^{7}$ The Jesuits and other missionary orders often identified themselves as "harvesters of souls" laboring in "the Lord's vineyard," and in Parras, winemaking became a complementary metaphor for the Jesuits' evangelization interests. ${ }^{8}$

6 Francisco de Urdiñola's granddaughter married the first Marqués de San Miguel de Aguayo, Agustín de Echeverz y Subiza, who moved from Madrid to Urdiñola's Hacienda de los Patos outside of Parras, thus joining Urdiñola's vineyards with the domains of the Marques. See Vito Alessio Robles, Francisco de Urdiñola y el norte de Nueva España (Mexico City: Imprenta Mundial), 154, 211; Corona Páez also cites Alessio Robles in Vitivinicultura, 34.

7 Winemaking in Parras remains a thriving business today, as the Madero family that owns the Casa Madero label cultivates the vineyards formerly controlled by the Jesuits and other colonial hacendados.

8 This biblical metaphor of the northern missions as the Lord's vineyard appears repeatedly in Andres Pérez de Ribas's 1645 History of the Triumphs of Our Holy Faith, trans. Daniel Reff, Maureen Ahern, and Richard Danford (Tucson: University of Arizona Press, 1999), 


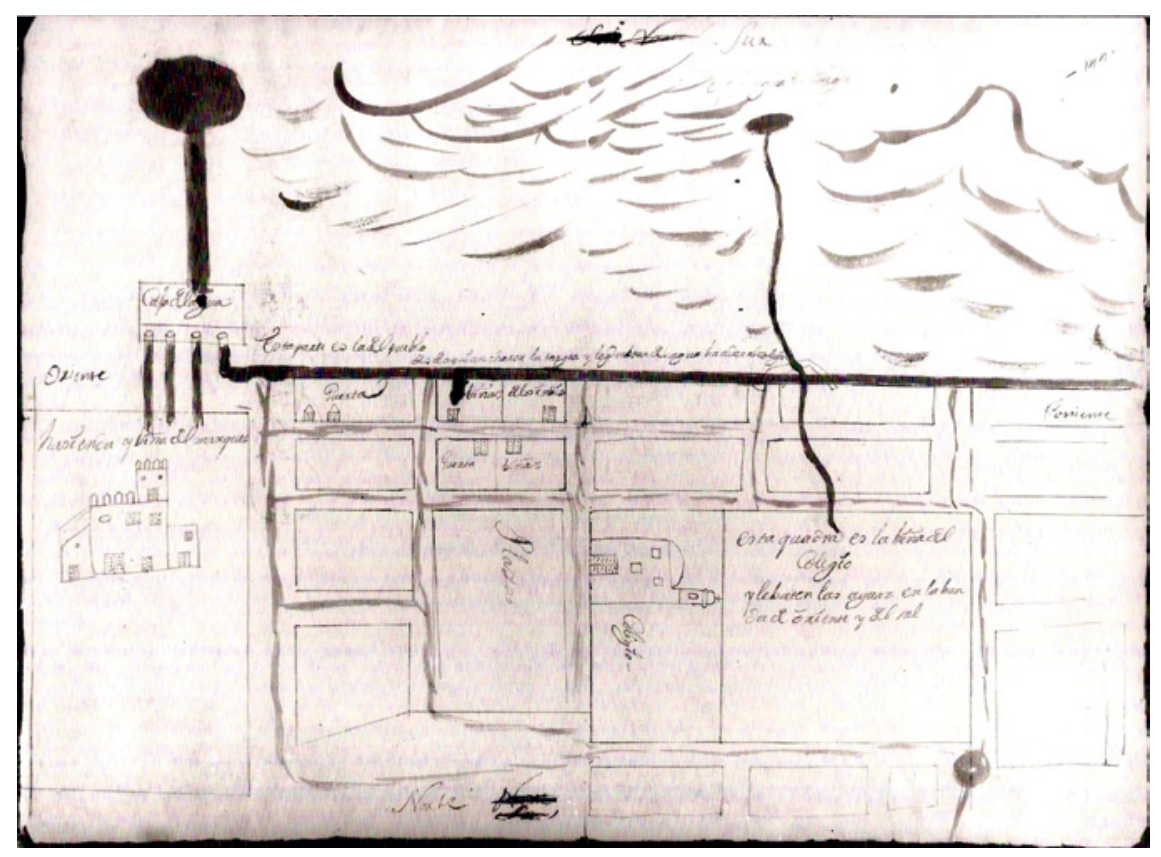

FIGURE 6.2 Map of Parras c.1670

ARCHIVO GENERAL DE LA NACIÓN, MEXICO CITY

Preachers often conflated their spiritual and temporal interests from the pulpit, stating, "We live in the land of beautiful vistas and flourishing vineyards. Today our teachings provide for the cultivation of the spiritual vine." In exchange for masses said in honor of their benefactors, Jesuit missionaries received through donations six large vineyards and precious water sources from prominent landowners. ${ }^{10}$ This use of sermons reinforced the priorities of the Jesuits to establish these relationships with wealthy landowners in Parras both through economic transactions and through teaching and preaching from the pulpit.

11:655. John O'Malley also notes that Jesuit discourses often used viticulture metaphors in, Religious Culture in the Sixteenth Century (Brookfield: Variorum, 1993), 297-99.

9 Archivo General de la Nación, Mexico City [hereafter AGN], Archivo Histórico de la Hacienda [hereafter AHH], vol. 972, Exp. 1B. These sermons are not numbered, nor are they organized chronologically. I have created this numbering system beginning with the first sermon from Parras. This sermon is number twenty-nine in this sequence.

10 In the viceroyalties of Peru and New Spain, the Jesuits created revenues for their colleges by operating their own haciendas, ranches, and vineyards as well as renting urban properties. See Cushner, Lords of the Land: Sugar, 5. At Parras, the Jesuits reaped substantial profits, which averaged ten thousand pesos in silver annually. This income often outperformed the revenues at larger colleges such as Durango and León in northern New Spain. See Archivum Romanum Societatis Iesu [hereafter ARSI], Mex. 6, fol. $211^{\text {r }}$. 
As the Jesuits fostered alliances with other families in Parras to serve their religious and temporal interests, these patrons donated funds to decorate chapels in the Jesuit church of San Ignacio de Loyola. The order's involvement with these diverse, multigenerational groups of landowners at the northeastern limits of the Mexican province allowed the Jesuits to create complex webs of artistic exchange between metropolitan and mission settings. While this practice of donors paying for artworks to publicly present themselves as supporters of the Jesuits functioned as a symbol of power in Santa María de las Parras, this tradition was not unique to northern New Spain. Scholars have documented similar practices in many cities throughout Spanish America, Europe, and Asia in the Early Modern period. ${ }^{11}$ Yet this dynamic of public financial support for the Jesuits operated under unique circumstances in Parras on the northern fringes of the viceroyalty. Here, Spanish and indigenous leaders maintained mutually beneficial relationships with the Jesuits to sustain lucrative vineyards and ranching operations and defend the Spanish presence on the northern frontier. Fueled by their economic success in winemaking, the Jesuits were able to ally themselves with these patrons and import artworks from prominent artists in Mexico City. The Jesuits commissioned paintings with specific iconographies and imported them on their frequent travels between Europe, central Mexico, and their missions. ${ }^{12}$ The Jesuits also had a specific interest in artworks by master artists working in both New Spain and Europe. ${ }^{13}$ Scholars have revealed that the Jesuits transported works by renowned artists to their missions, where paintings such as Jose de Páez's San Juan Nepomuceno still

11 For more on the relationship between Jesuit patronage and political power in Italy, Mexico, Peru, and Asia, for example, see Olwen Hufton, "Altruism and Reciprocity: The Early Jesuits and Their Female Patrons," Renaissance Studies 15, no. 3 (2001): 328-53; Carolyn Valone, "Architecture as a Public Voice for Women in Sixteenth-Century Rome," Renaissance Studies 15, no.3 (2001): 301-27; Autrey Maza and Rodríguez Castañeda, La Profesa: Patrimonio artístico; Tom Cummins, "Argumentos milagrosos: Pintura y política cultural tras el terremoto de 1650," in Pintura cuzquena (Lima: Asociación Museo de Arte de Lima, 2016), 73-93. Valerie Fraser, "Architecture and Ambition: The Case of the Jesuits in the Viceroyalty of Peru," History Workshop Journal 34, no. 1 (Autumn 1992): 16-32.

12 Clara Bargellini, "Art at the Missions of Northern New Spain," in The Arts of the Missions of Northern New Spain, ed. Clara Bargellini and Michael K. Komanecky (Mexico City: Antiguo Colegio de San Ildefonso, 2009), 54-94, here 70; Katherine Moore McAllen, "Rethinking Frontier Paradigms in Northeastern New Spain: Jesuit Mission Art at Santa María de las Parras, 1598-1767" (PhD diss., Harvard University, 2012), 69-115, here 75.

13 Luisa Elena Alcalá, "The Jesuits and the Visual Arts" (PhD diss., New York University, 1998), 126-71, 132. Clara Bargellini, Misiones para Chihuahua (Mexico City: мвм Impresora, 2004), 67 . 
hang in situ in the Jesuit church of Santo Tomas Tejoraré, in present-day Chihuahua, Mexico.

While it has been suggested that the competitive nature of painting production in Mexico City explains why artists were motivated to send their works to cities outside of the viceregal capital, documents from Parras provide further evidence that members of the Society of Jesus played an active role in the circulation of artworks by leading masters throughout the viceroyalty. ${ }^{14}$ The Jesuits also provided a thriving market for these painters through their demand for artworks at their missions and colleges in northern New Spain. As Jesuit missionaries' travels to the viceregal capital kept them aware of the most soughtafter painters, they specifically requested paintings by master artists working in Mexico City. Jesuit missionaries identified works by masters such as Miguel Cabrera (1695-1768), Cristobal Villalpando (1649-1714), and José de Páez (172790) in their church inventories in the north..$^{15}$ These artists, whose paintings were transported to the missions, often identified their place of profession in Mexico City along with their signatures, with the phrase "en Mexico," as seen in Miguel Cabrera's c.1749 portrait of The Martyrdom of Hernando de Santarén, a Spanish Jesuit who died in the 1616 Tepehuan Indian Revolt in Durango. ${ }^{16}$

While the Jesuits were involved in acquiring paintings from Mexico City and transporting them to the north, the important role of local donors in this dynamic web of artistic exchange at the missions is a subject that deserves further scholarly attention. ${ }^{17}$ Some works have been found inscribed with

14 Rogelio Ruíz Gomar observes: "Given the strong competition in Mexico City, both Torres and [Francisco] Martínez must have had to look for commissions outside that area, principally in northern Mexico," in "Unique Expressions: Painting in New Spain," in Painting a New World: Mexican Art and Life, ed. Donna Pierce, Rogelio Ruíz Gomar, and Clara Bargellini (Austin: University of Texas, 2004), 71.

15 This identification of the artist's place of work is also included in José de Páez's painting of San Juan Nepomuceno in the mission church of Santo Tomás, Tejoraré, Mexico. See Clara Bargellini, Misiones y presidios de Chihuahua (Chihuahua: Gobierno del Estado de Chihuahua, 1997), 51. See also Luisa Elena Alcalá, Jaime Cuadriello, Ilona Katzew, and Paula Mues Orts, "Pintado en Mexico, 1700-1790," in Painted in Mexico: 1700-179o: Pinxit Mexici, ed. Ilona Katzew (Los Angeles: Los Angeles County Museum of Art; Mexico City: Fomento Cultural Banamex, 2017): 16-51, here 17 and 38 .

16 Katherine McAllen, "Jesuit Martyrdom Imagery between Mexico and Rome," in The New World in Early Modern Italy, 1492-1750, ed. Lia Markey and Elizabeth Horodowich (Cambridge: Cambridge University Press, 2017), 143-65, 151.

17 Bargellini mentions that the saints presented in a painting at the church of Santiago Papasquiaro suggest the existence of donations by private parties in "Art at the Missions of Northern New Spain," 81. For more on references to local participation in donations to church decoration programs, see Bargellini, "At the Center on the Frontier," in Time and 
patrons' names, as seen in the painting of San Francisco Javier Baptizing from the Jesuit church of San Lorenzo in present-day Belisario Domínguez, Chihuahua, Mexico. An inscription identifies the patron, whose name is no longer legible on this canvas: "A Devoción Del Capi(tán) Don Francisco" (paid for by Captain Don Francisco). ${ }^{18}$ Often, little is known about how patrons influenced the selection of artworks and iconographical programs at the missions due to the difficulty of reconstructing this visual evidence that often no longer exists. ${ }^{19}$

While the destruction or dispersal of artworks makes it difficult to understand the original nature of church decorations in these religious spaces, Parras presents a unique case study for key reasons: one, despite inevitable changes to the interiors of Jesuit churches, especially after the Society's Expulsion in 1767, many of the artworks from San Ignacio de Loyola have survived and two, the original decoration program of the church can be connected to donations of local patrons. Primary sources and textual descriptions of the church before 1767 record the original placement of paintings within this single aisle nave church opening onto side chapels with sixteen gilded altar retablos (Figure 6.3). The survival of these original artworks and records of donations to the Jesuits provide an opportunity to shed light on the involvement of patrons and allow a nearly comprehensive reconstruction of the decoration of San Ignacio de Loyola. ${ }^{20}$ These documents also reveal how economic initiatives were often

Place: The Geohistory of Art, ed. Thomas DaCosta Kaufmann and Elizabeth Pilliod (Aldershot: Ashgate, 2005), 114.

18 While this canvas has been damaged over time, leaving the name of the patron illegible, Clara Bargellini posits that this patron may have been Francisco Javier Campa, who was most likely a captain of the northern provinces before $175^{\circ}$. Bargellini has researched this canvas, which she dates to the first half of the eighteenth century, based on a reference from Bishop Pedro Tamarón y Romeral's 1759 visit to this mission, in which he identifies a painting of San Francisco Javier hanging in the nave of the Jesuit church in San Lorenzo. See her "Rescate del olvido" (paper presented at Diagnóstico en defensa del patrimonio: XIII Coloquio del Seminario de Estudio y Conservación del Patrimonio Artístico, Morelia, Mexico, September 2005), 14-16.

19 Gloria Giffords mentions two known paintings inscribed with the patrons' names in the north, one of the Virgin of Sorrows in the Capilla del Cristo de Mapimí in the Chihuahua Cathedral that connects the Calderón family with the donation of this image and retablo in 1762, and a painting of San José by José de Páez at San Francisco de Mapimí that contains an inscription identifying the donation of this piece by Pedro Nicolás de Cadrecha. Giffords also identifies a rare example of donors' portraits at San Sebastian in Concordia in Sonora, where the sculptures of two donors flank the sacristy entrance. See Giffords, Sanctuaries of Earth, Stone, and Light: The Churches of Northern New Spain (Tucson: University of Arizona Press, 2007), 318, 331.

20 Few near-complete reconstructions of church interiors exist. For example, see María del Consuelo Maquivar, Los retablos de Tepotzotlán (Mexico City: INAH, 1976), 25; Carlos 


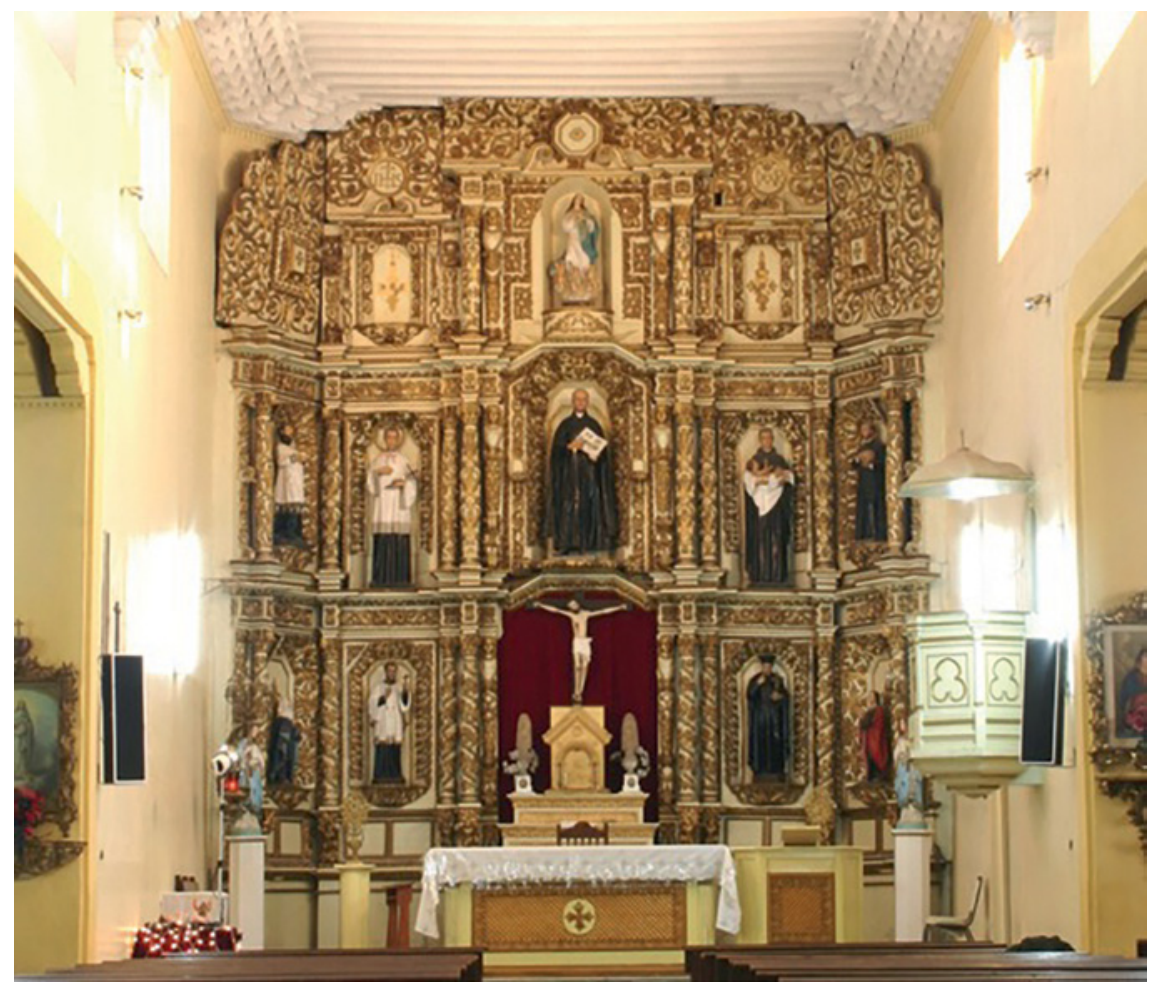

FIGURE 6.3 Church of San Ignacio de Loyola, Parras. Altar Mayor (High Altar) PHOTO BY JAMES MCALLEN, JR.

intertwined with art production, as the Jesuits decorated their chapels and commissioned artworks according to the financial support of local landowners, who cultivated vineyards near their own.

As the Jesuits' spiritual and temporal enterprises became interconnected, they received other donations from wealthy lay patrons to build and decorate their church. Documents record that the church of San Ignacio de Loyola in Parras existed by 1622, and by the year of the order's Expulsion in 1767 , the Jesuits had transformed this mission to a residence and constructed a monumental church within this complex with a large, single-aisle nave and nine side

Manuel Valdés Dávila and Ildefonso Dávila del Bosque, Los tlaxcaltecas en Coahuila (Tlaxcala: Gobierno del Estado de Tlaxcala, 1999), 227-31. 
chapels. ${ }^{21}$ In 1641 , the bishop of Durango, Diego de Evia y Valdés (1587-1656), established a secular church in Parras, in part as an attempt to end the Society's presence in Parras by replacing their mission with a diocesan church. ${ }^{22}$ Rather than abandon their spiritual and temporal interests, the Jesuits began the process of transforming San Ignacio de Loyola into a colegio incoado (inchoate college), which later became a residencia (residence), as a strategic move to retain ownership of its vineyards and valuable water sources. ${ }^{23}$ This transitional status allowed the order to take advantage of special financial privileges, such as owning properties for the upkeep of their inchoate college or residence while not having to forfeit their royal mission stipends as formal colleges did. ${ }^{24}$ In his Constitutions, Ignatius of Loyola sought to ensure that Jesuit colleges and Jesuit residences seeking college status, also known as inchoate colleges, could support themselves and permitted them to create a steady source of income. ${ }^{25}$ While the Jesuit house at Parras is often identified as an inchoate college in the 1640 , there is some discrepancy over whether San Ignacio de Loyola was officially classified as a college after the middle of the seventeenth century. ${ }^{26}$ While historian José Gabriel Martínez Serna suggests that the Jesuits transformed their mission into a residencia and then later an inchoate college, documents in the Jesuit archive in Rome reveal that the reverse may

21 For a discussion of San Ignacio de Loyola's transformation from mission to inchoate college, see Agustín Churruca Peláez, El sur de Coahuila en el siglo XVII (Torreón: Editorial del Norte Mexicano, 1994), 193. For primary sources, see ARsi, Mex. 5, fols. 251 ${ }^{\mathrm{v}}, 293^{\mathrm{v}}, 33^{\mathrm{v}}$.

22 José Gabriel Martínez Serna presented a detailed analysis of the various events that led to Bishop secularizing the Jesuits' mission at Parras, which included Jesuit disputes with the Urdiñola family over water rights and treatment of the Indians, in which Spanish landholders sought to acquire the Jesuits' coveted vineyards if their mission was secularized. See Martínez Serna, "Vineyards in the Desert: The Jesuits and the Rise and Decline of an Indian Town in New Spain's Northeastern Borderlands" (PhD diss., Southern Methodist University, 2009), 90-91.

23 Martínez Serna, "Vineyards in the Desert," 7.

24 While little is known about how these frontier colleges-in-transition functioned, the Jesuits established similar colegios incoados on the frontiers of the southern viceroyalty at Arauco in Peru, at Honda in Nueva Granada in present-day Colombia, and at San Juan de la Frontera in Cuyo, present-day Argentina. See Martínez Serna, "Vineyards in the Desert," 113 .

25 Ignatius of Loyola, The Constitutions of the Society of Jesus and their Complementary Norms: A Complete English Translation of the Official Latin Texts, trans. John W. Padberg, S.J. (Saint Louis: The Institute of Jesuit Sources, 1996), 135, 177.

26 Agustín Churruca Peláez provides a preliminary examination of whether San Ignacio de Loyola was a "residencia” or a "colegio" in his chapter, “¿Hubo colegio en Parras? ¿Cuándo?” in El sur de Coahuila en el siglo XVII (Torreón: Editorial del Norte Mexicano, 1994), 193-96, here 194 . 
actually be true. In 1681, Parras was officially recognized as a "Collegium Inchoatum," and by 1684 it is identified as a residence. ${ }^{27}$ Even though the decree to secularize the mission was created in 1641 by Bishop Evia y Valdés, the Jesuits delayed the implementation of this decree in their litigious debates and continued to organize a decoration program with the help of Spanish and Tlaxcalan vineyard owners. ${ }^{28}$

In the $1670 \mathrm{os}$, the periods of economic success in winemaking were often followed by periods of strong patronage for the Jesuits when vineyard owners established and increased the number of donations to the order. For example, the initiation of brandy distillation in Parras in 1659 created an increase in liquor production in northern New Spain. By 1667 , the demand for brandy caused the alcoholic beverage market to expand into more locations and mining towns such as Zacatecas. ${ }^{29}$ Beginning in 1680 and well into the eighteenth century, winemakers were able to sell half the volume of brandy for double the cost of wine. In the 1670 s, the Jesuits began a substantial decoration campaign at the inchoate college church of San Ignacio de Loyola upon receiving large donations by lay patrons to fund the construction and decoration of new chapels. ${ }^{30}$ The renewed need for water sources to cultivate their vines also gave landowners a reason to support the Jesuits, who shared partial ownership of the pueblo's lakes with prominent Tlaxcalan and Spanish families. Local patrons, such as the Estradas, a prominent Spanish family who amassed their fortunes from winemaking, donated funds for the decoration of the monumental, gilded main altar in San Ignacio de Loyola beginning in 1679 (Figure 6.4). The inclusion of grapevine motifs carved into the gilded columns of this retablo made a clear visual reference both to the sacrament of the Eucharist and to the winemaking that was so important to these patrons. Donations from the

27 This data is recorded in the Jesuit Catalogi Triennales et Breves in ARSI, Mex. 5, fols. $25^{\mathrm{v}}$, $293^{\mathrm{v}}$, and $33^{8}$. These reports sent to Rome approximately every three years identify Parras as a mission as late as 1679 . In 1681, it is recognized officially as the "Collegium inchoatum Parras," and subsequently in 1684 , Parras is recognized as a residencia.

28 These debates with the Bishop gave the Jesuits time to transform San Ignacio de Loyola into a residencia. For more on this, see Martínez Serna, "Vineyards in the Desert," 9o. For the original dialogue of this debate between the Jesuits and the bishop of Durango that continued for more than ten years, see AGN Jesuitas 64, vol. 33, exp. 82, fol. 250 (September 9, 1648); AGN Jesuitas 64, vol. 33, exp. 83, fol. 252 (July 12, 1649); AGN Jesuitas 64, vol. 33, exp. 79 (July 4, 1651).

29 Corona Páez, Vitivinicultura, 44.

30 For example, in 1679, the Antonia Estrada family made a donation to adorn the altar mayor suggesting that some part of the main retablo must have already been built by this time. Archivo Histórico del Colegio de San Ignacio de Loyola de Loyola de Parras, Universidad Iberoamericana Laguna, Torreón [hereafter AHCSILP], Expediente 133. 


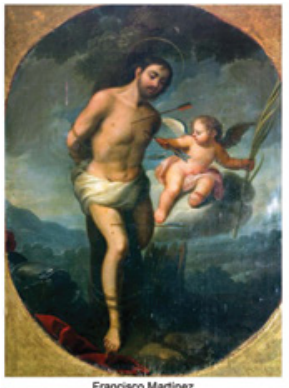

Francive Martines

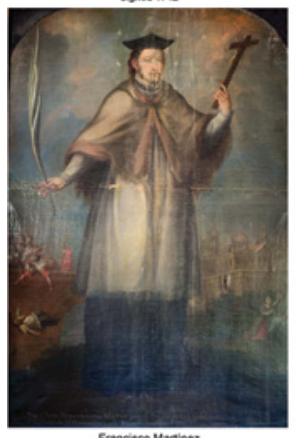

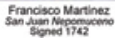

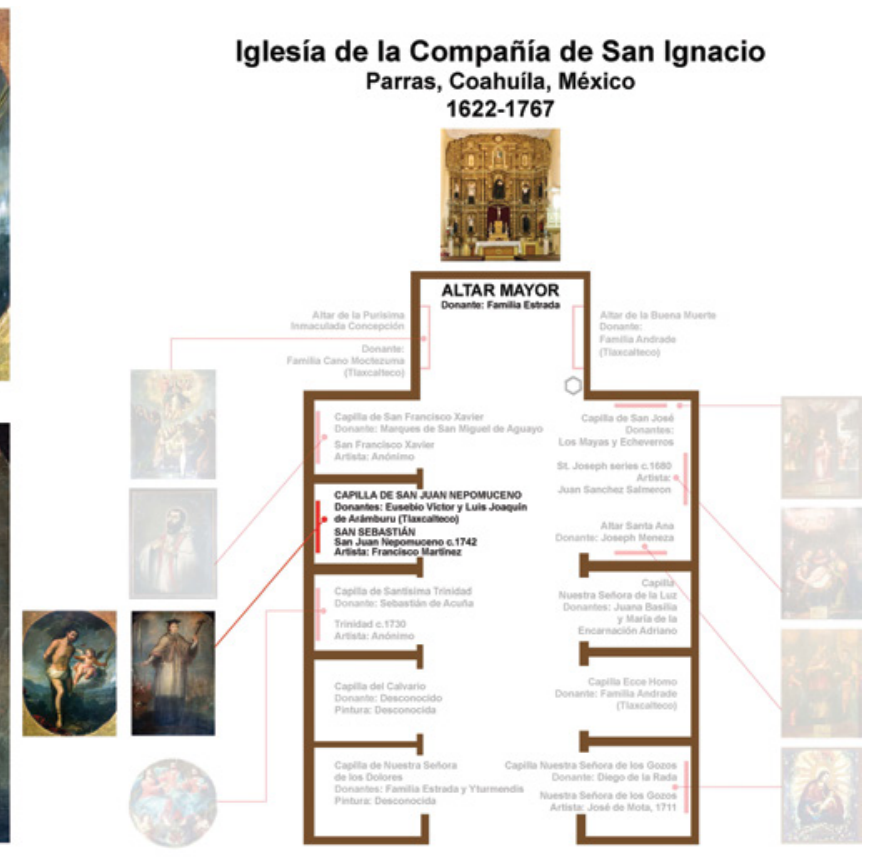

FIGURE 6.4 Church reconstruction plan of San Ignacio, Parras

SPECIAL THANKS TO CARLOS LIMAS AND LETICIA LOWRY DE GARCILASO

Estrada family that continued throughout the eighteenth century were given to help the Jesuits commission a sculptural altar in the apse of the church. ${ }^{31}$ This main altar presented Jesuit saints including St. Ignatius of Loyola $\left(c .1491-155^{6}\right)$ at the center surrounded by saints such as St. Francis Xavier (1506-52) and St. Francisco de Borja and beatified Jesuits Stanisław Kostka (1550-68) and Luigi Gonzaga (1568-91). This organization of Jesuit saints and beatified members of the order presented within the retablo of the high altar echoed the precedent established in the Jesuit church of La Profesa in Mexico City. ${ }^{32}$

31 In 1693, Antonio de Estrada founded a two-thousand-peso annual capellanía (proceeds from a real estate donation to the Jesuits). Antonio's donation stipulated that the funds were to be given to the Jesuits in perpetuity, which were continued to be paid by his son, Francisco. Isabel de Estrada (b.1670), Antonio's daughter, would continue this patronage for the Jesuits in 1738 by providing the order with a censo (annual pension) of one thousand pesos. See AHCSILP, Expediente 313; A HCSILP, Expediente 133. See also Corona Páez, Vitivinicultura, 185 .

32 Rogelio Ruíz Gomar, "El retablo de La Profesa y su efímera transfiguración en 1672," in Los discursos sobre el arte: XV Coloquio internacional de historia del arte (Mexico City: UNAM, 1995), 91-106. 
While the Estrada family helped fund the decoration of the main altar with a pantheon of Jesuit saints, other local Spanish patrons played an active role in selecting their own devotions within the Jesuits' decoration program. The chapel dedicated to San José was the largest and most elaborately decorated chapel in San Ignacio de Loyola due to the support of its principal patrons, the families of the Marqués and Marquesa de San Miguel de Aguayo. The various Marqueses and their relatives funded the construction and decoration of the San José chapel beginning in $1680 .^{33}$ Relatives of the Marqués, such as Ignacio de Amaya (b.1677) and his family, pledged their financial support to this chapel for multiple generations. ${ }^{34}$ Captain Ignacio de Amaya was the cousin of José de Azlor (d.1734), the second Marqués de San Miguel de Aguayo, and Ignacia Xaviera de Echeverz y Valdéz (1679-1733), who together were the largest landholders in northern New Spain in the late-seventeenth and eighteenth centuries. Ignacio de Amaya's family revealed his pride in the adornment of the Jesuits' church of San Ignacio de Loyola in Parras when he stated it was "the most beautiful church in this land." 35 Funded by the frequent donations of the Maya y Echeverz family for devotions to Saint Joseph, the Jesuits commissioned a prominent artist from Mexico City, Juan Sánchez Salmerón (d.1697), to produce a series of five paintings depicting scenes from the Life of the Virgin, including the Annunciation and Dream of San José (Figure 6.5). ${ }^{36}$ Frequently employed by the Jesuits, Salmerón worked at La Profesa in Mexico City and at the novitiate in Tepotzotlán in 1681, where his patrons described his talents as equal to those of contemporary painters Juan Correa $(1646-1716)$ and Baltasar de Echave y Rioja (1632-82). Each image in this series presents a unique variation on traditional Marian iconographies by focusing on the role of Saint Joseph as the patriarch of the Holy Family. To the left of the Virgin, the Archangel Gabriel appears in a separate scene to restore Joseph's faith in Mary, as recounted in the Gospel of Matthew. In his arrangement of this composition separating distinct architectural spaces and outdoor settings, we can see that

33 In his donation from 1681, for example, Ignacio de Maya, a cousin of the Marques, mentions the Jesuit church in Parras had two chapels that remained undedicated. Within one, he decided to establish the Chapel of Saint Joseph in San Ignacio de Loyola. See AGN, Jesuitas I-33, Expediente 77, February 26, 1681.

34 The de Amaya and Echeverz families were the most influential Spanish donors to the Jesuits in Parras. For these patrons' plans to be buried under these chapels, see Agustín Churruca Peláez, El Sur de Coahuila en el siglo XVII (Torreón: Editorial del Norte Mexicano, 1994), 167 .

35 For this statement, see AGN, Jesuitas I-33, Expediente 77, 26 February 1681.

36 In a letter to the Father Provincial in Mexico City, the missionary Tomás de la Jana wrote from Parras about Ignacio's donation to receive approval from the Father Provincial. See AGN, Jesuitas I-33, Expediente 77. 


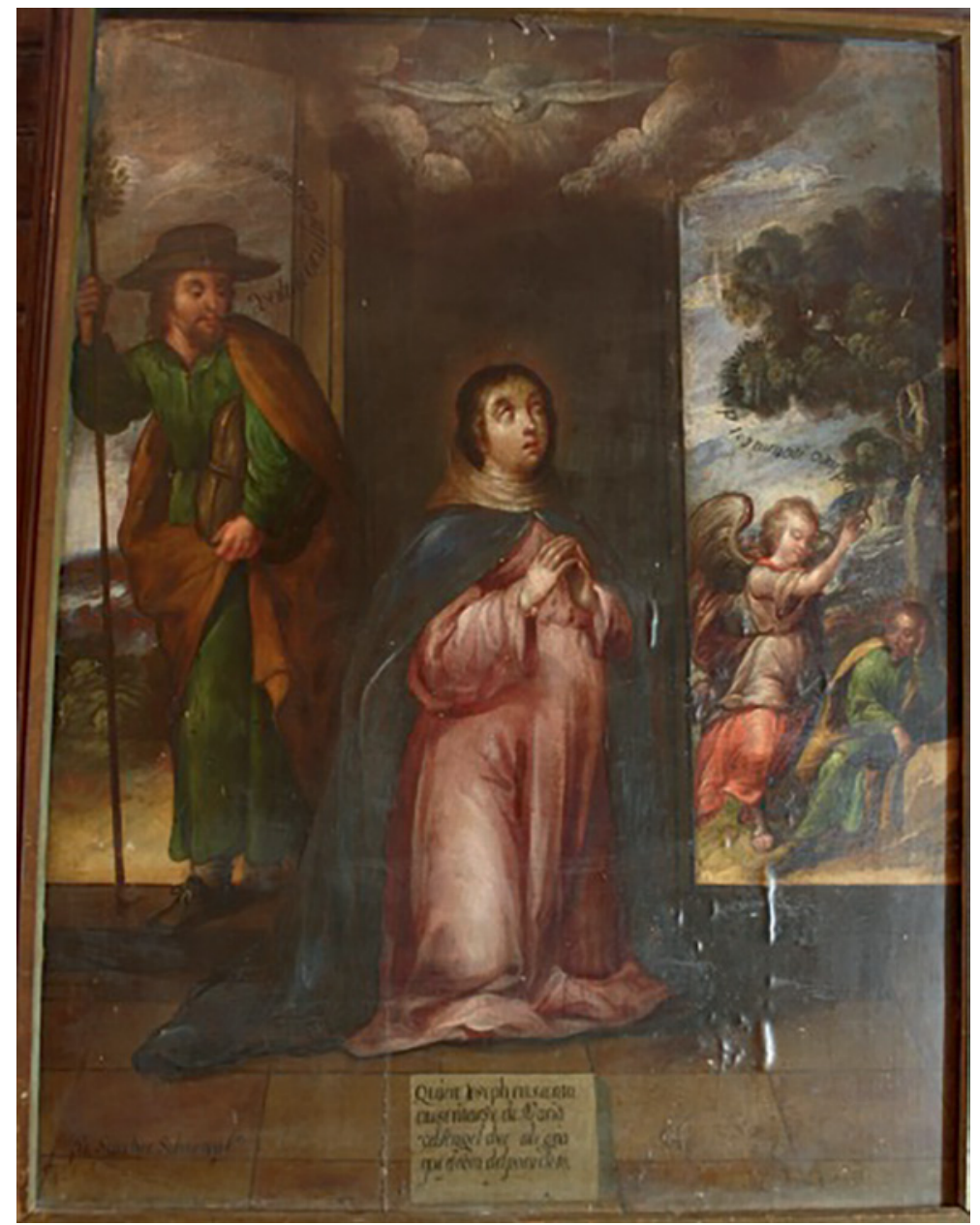

FIGURE 6.5 Juan Sánchez Salmerón, Annunciation and Dream of San José. Colección de pintura religiosa de la Universidad Iberoamericana Torreón, Coahuila, México, $c .1681$

COURTESY OF THE UNIVERSIDAD IBEROAMERICANA, TORREÓN

Salmerón likely consulted Jerónimo Nadal's (1507-80) influential Jesuit treatises Evangelicae historiae imagines and his Adnotationes et meditationes, which were published in Antwerp in 1594 and 1595 (Figure 6.6). ${ }^{37}$ Salmerón could

37 Tom Cummins makes this observation about Nadal's influential treatise serving as a source for Spanish colonial paintings and drawings in, "The Indulgent Image: Prints in the New World," in Contested Visions in the Spanish Colonial World, ed. Ilona Katzew (Los Angeles: Los Angeles County Museum of Art, 2012), 203-26, here 221. 


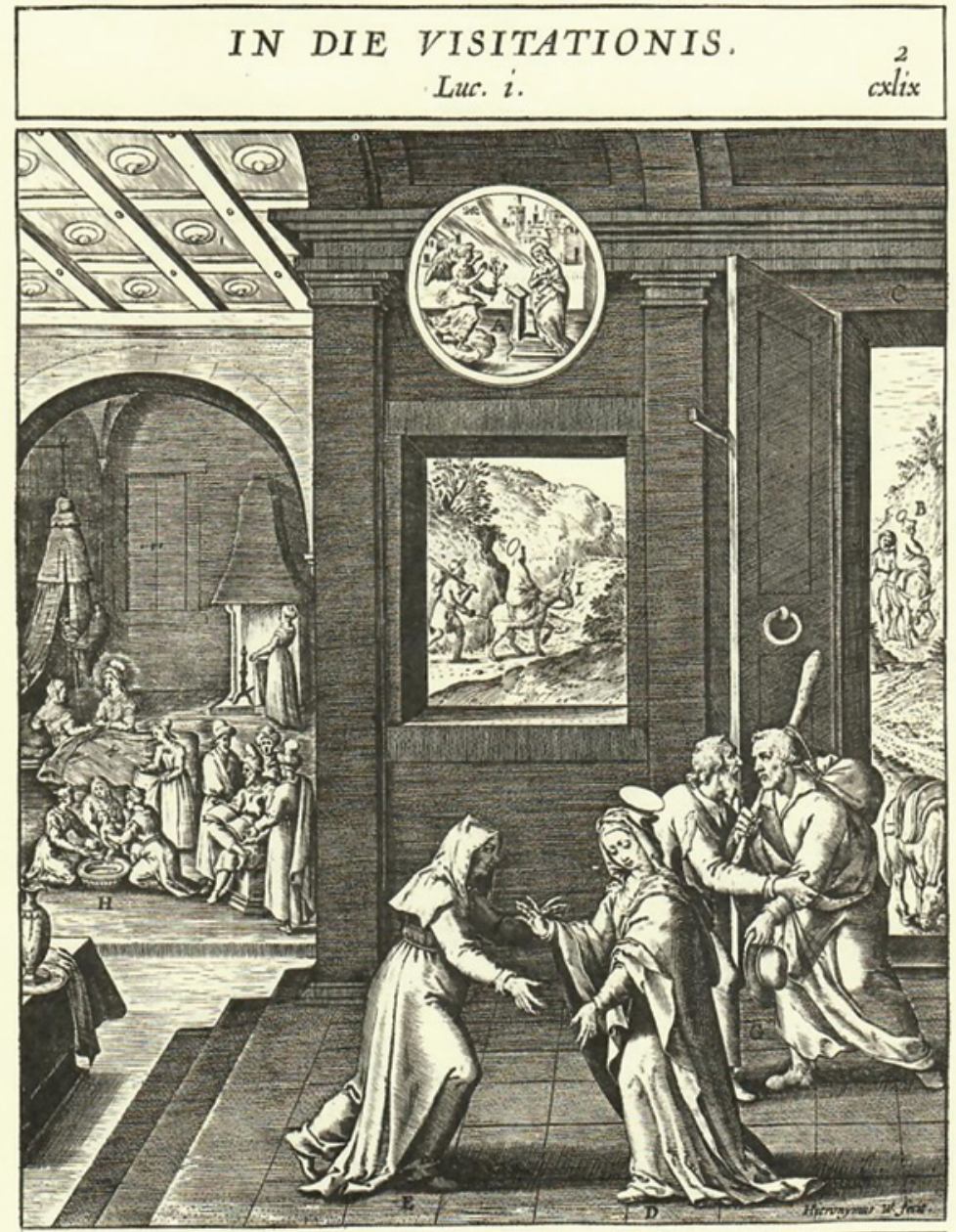

A. Nazereth, vbi reprefentatur Anmunti: atio, poft quam Virgo Mater ftatuit Elisabetham imuisere.

B. Iter habet Maria feftimanter cum Iofeph ad montana Iudace.

C. Domus Zacharia in tribu Iuda in montibus. D. Ad quam cum peruenißet Maria festi: nanit ad Elisabeth.

E. Sedula illi Anus acurrit, fed eam tamen prior falutat Maria .

F. Audita Matris Dei falutatione, ecce exultat in vterv Elisabeth Filus, ov repletur Suiritu fancto Mater, ¿ pradicat Maria diuma encomia .

G. Zacharias of Iofcph laudant Deum.

H. Nascitur Ioannes.

I. Post exus ortum, redit Nazareth Maria Virgo Mater cum Iofeph.

FIGURE 6.6 Jerónimo Nadal, "The Visitation of the Virgin," in Evangelicae historiae imagines ANTWERP, 1594-95

have seen these engravings by Nadal, such as The Visitation of the Virgin, while working at various Jesuit houses in Mexico City.

Ignatius of Loyola's Spiritual Exercises and Jerónimo Nadal's Evangelicae historiae imagines were the order's most important meditation manuals that 
stressed the role of images for inspiring devotion. While Loyola encouraged participants of the Exercises to construct mental images of religious subjects via mnemonic techniques of "seeing the place," Nadal used actual images identified by lettered captions and texts to encourage "seeing" and "reading" as a simultaneous devotional practice. ${ }^{38}$ The Jesuits owned copies of Nadal's Evangelicae gospel engravings that accompanied his Adnotationes et meditationes in their houses and colleges in Mexico City. The library at San Ignacio de Loyola in Parras also held a copy of Nadal's devotional book, allowing priests to see Nadal's depiction of multiple scenes in the same narrative. ${ }^{39}$ The Annunciation and Dream of San José by Salmerón presents a Nadalian-inspired composition that provides captions in the bottom quadrant of the canvas. Here Salmerón presented Nadal's devotional strategy of encouraging the viewer to contemplate words and images at the same time, a practice that was affirmed in artworks as well as expressed in Jesuit sermons that drew attention to these artworks displayed in front of the church congregation.

In addition to the series by Salmerón, the Jesuits imported paintings by other master artists working in Mexico City, such as two works by Francisco Martínez (d.1758). In the chapel of San Juan Nepomuceno, the donations of the Tlaxcalan Arámburu family in the eighteenth century provided the funds for the Jesuits to transport Martinez's San Sebastián and San Juan Nepomuceno to Parras (see Figure 6.4). Church inventories confirm the existence of a retablo dedicated to themes of martyrdom, which contained a large painting of San Juan Nepomuceno, which is most likely the piece signed by Martínez in Mexico City in 1742 that survives today in San Ignacio de Loyola in Parras.

The rise to prominence of Tlaxcalan landowners, who emigrated to Parras from Tlaxcala in the Valley of Mexico, also provided the Jesuits with an important patronage group whose relationship was based on their elite indigenous origins. Parras was founded legally as a Spanish and Tlaxcalan pueblo where both

38 Carmen Fernández-Salvador observes that Nadal's engravings stressed the "inextricability of place and images as the basis for intellectual consideration" in which "the reader must consult words and pictures at the same time." See Fernández-Salvador, "Images and Memory: The Construction of Collective Identities in Seventeenth-Century Quito" (PhD diss., University of Chicago, 2005), 39-40.

AGN, Temporalidades, vol. 64 , fol. $63^{\text {r }}$. 
ethnic groups shared power in the same local government and participated in the viticulture business. ${ }^{40}$ Indigenous families from the Tlaxcalan Republic in the Valley of Mexico emigrated to northeastern New Spain at the request of the viceroy in 1591 to aid in the conversion and pacification of Indian tribes, just as they had done as allies to the Spanish in the Valley of Mexico before and after the Conquest. ${ }^{41}$ These Tlaxcalan families in Parras, who claimed direct descent from the Tlaxcalan lord Xicotencatl, received various privileges, titles, and land grants for relocating to this "altepetl norteño" (or Nahua ethnic citystate in the north) in Parras and nearby Saltillo.

To maintain their status as prominent members of the local community and receive the aid of the Jesuits in local lawsuits to protect their lands, these families became generous benefactors of San Ignacio de Loyola. Always identifying themselves as "indios de los naturales tlaxcaltecos" (indigenous Tlaxcalan Indians) in documents, these indigenous patrons contributed to the Jesuits' creation of an "episodic" artistic program in San Ignacio de Loyola. ${ }^{42}$ Tlaxcalan members of the Arámburu, Cano Moctezuma, and Andrade families funded the construction of two large retablos flanking the main altar and two other chapels along the nave. Inventories reveal that paintings, such as the Assumption of the Virgin by Agustín del Pino signed in 1711, once adorned the Altar of the Immaculate Conception paid for by the Cano Moctezuma family, who were in Parras by the end of the sixteenth century. Interestingly, with the demographic heterogeneity of Spanish and indigenous families actively participating in patronage projects at San Ignacio de Loyola, Tlaxcalan donors did not fund the production of images with indigenous iconographies. Nevertheless, as Parras became a unique locus of cultural and racial exchange on the northern frontier, the artworks paid for by indigenous patrons became an important part of the Jesuits' organized decoration program.

40 Corona Páez, Viñedos y vendimias en la Nueva Vizcaya, 26-31.

41 Carlos Manuel Valdés Dávila and Ildefonso Dávila del Bosque, Los Tlaxcaltecas en Coahuila (México: Gobierno del Estado de Coahuila, 1999); Elisabeth Butzer, Historia social de una comunidad tlaxcalteca: San Miguel de Aguayo (Bustamante, Nuevo León), 16861820 (Saltillo: Archivo Municipal de Saltillo/Austin: Department of Geography University of Texas/Tlaxcala: Instituto Tlaxcalteca de la Cultura/ Nuevo León: Presidencia Municipal de Bustamante, 2001).

42 Jaime Cuadriello uses this phrase in his examination of the active role Tlaxcalan patrons played in the creation of the decoration program of the Yehualtepec parish church in Tlaxcala in the 1780 s, in The Glories of the Republic of Tlaxcala: Art and Life in Viceregal Mexico, trans. Christopher J. Follett (Austin: University of Texas Press, 2011), 117. 
Other Spanish patrons donated funds to construct chapels across from chapels paid for by Tlaxcalan families in San Ignacio de Loyola. Diego de la Rada, a prominent Spanish vineyard owner and member of Parras's local government in the eighteenth century, was the principal donor for the Chapel of Nuestra Señora de los Gozos (Our Lady of Joys). The large painting identified in inventories as the centerpiece of the retablo of Our Lady ofJoys survives today in San Ignacio de Loyola and is signed by another master artist from Mexico City, José de Mota (see Figure 6.3). The duality of iconographies in this painting, with lilies honoring the celestial miracle of the Virgin's conception and roses alluding to the rosary and the physical motherhood of Mary, functioned as a special devotion for the de la Rada family during private masses.

These paintings from Parras also provide important evidence related to the question of original viewership in San Ignacio de Loyola as the details of these compositions are described in sermons and other textual references. Within this setting, Jesuit orators referred to these devotional images in their homilies, encouraging audiences to actively engage with these images that acquired multiple meanings for different viewers. As Carmen Fernández-Salvador demonstrates in her study of sermons, "Seeing and hearing were performed in the sacred space of the church, as two concurrent, complementary, and almost in-

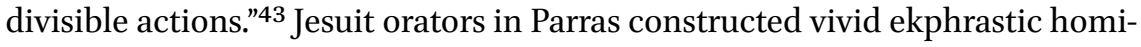
lies linking images and sacred buildings abroad to paintings and spaces in their church as a strategy to inspire devotion. ${ }^{44}$ Evidence from Parras confirms Fernández-Salvador's argument that the Jesuits' sacred rhetoric encouraged "the spectator to take an active role" in viewing devotional artworks so that "the act of 'seeing' was transformed into an intellectual operation." ${ }^{45}$ The archival preservation of sermons from Parras reveal that Jesuit orators also engaged repeatedly with the artworks before them. A sermon from 1737 dedicated to Our Lady of Joys provides one such example of this process in which images became active agents in the interaction between words and pictures at San Ignacio de Loyola. An anonymous Jesuit preacher used the repeated vineyard metaphor to address a painting of the Virgin in his sermon, which was most likely Our Lady of Joys located in the first chapel to the right of the church

43 Fernández-Salvador, "Images and Memory," 36.

44 One sermon, for example, encourages the congregation to take a mental tour of the temple of the militant church in the Heavenly Jerusalem and the Temple Solomon in Jerusalem, linking the different altars and spaces of the Palace of King Solomon to the plan of the church in Parras. See AGN, AHH, vol. 972, Expediente 1B, Sermon numbers 5 and 10. 
entrance: "Look, Mary, with those merciful eyes at this, your vineyard, for this is the vineyard that looks at the Virgin as the Mother of Mercy."46 Preachers at San Ignacio de Loyola often made similar comments such as "Look at the Virgin in this sacred image" and "the paintings show this," thus adding a visual dimension to their sermons that helped teach symbolic Christian concepts and elaborate on the exemplary lives of the saints. ${ }^{47}$

While this analysis only begins to uncover the complex relationship between images and sacred rhetoric at San Ignacio de Loyola, the evidence of sermons and reconstruction of the decoration program at San Ignacio de Loyola clearly indicates that the Jesuits were actively inspiring "uniform patterns of looking" in the "collective imagination" of their congregations in Parras on the northern Spanish American frontier, as they did in colonial Quito. ${ }^{48}$ These strategies operated simultaneously in multiple Jesuit houses in the northern and southern Spanish American viceroyalties because of the nature of Jesuit spirituality that used pictures and mental images as the starting point for religious devotion. ${ }^{49}$

The presence of the surviving paintings at Parras by artists such as Salmerón, Mota, and Martínez provides further evidence that, with the support of local patrons, the Jesuits created a sophisticated network for importing devotional art from Mexico City to Parras. The survival of paintings by artists working in Mexico City in the Jesuit church of San Ignacio de Loyola in Parras, as well as at other missions such as Santa María de las Cuevas in Chihuahua and Santiago Papasquiaro in Durango, demonstrates that many artworks were transported successfully by the Jesuits to the north. ${ }^{50}$ The order established mutually beneficial relationships with patrons to serve their spiritual, economic, and artistic needs in Parras, just as they did in Mexico City, Quito, and Rome.

46 AGN, AHH, vol. 972, Expediente 1A, Sermon number 41: “Nuestra Señora de los Gozos," fol. 1.

47 AGN, AHH, vol. 972, Expediente 1 A, Sermon number 54.

48 Fernández-Salvador uses these terms in "Images and Memory," 38.

49 This discussion was inspired by Jeff Smith's analysis of Jesuit image theory in relation to printed devotional treatises that incorporated both text and image in Jeffrey Chipps Smith, Sensuous Worship:Jesuits and the Art of the Early Catholic Reformation in Germany (Princeton: Princeton University Press, 2002), 36; for a detailed analysis on this subject in reference to Nadal's illustrated treatises, see also Walter S. Melion, The Meditative Art: Studies in the Northern Devotional Print, 1550-1625 (Philadelphia: Saint Joseph's University Press, 2009), 4-5, 122-25.

5o For more on missionaries' requests for artworks from Mexico City, see Luisa Elena Alcalá, "The Jesuits and the Visual Arts," 252. For more on Jesuit commissions from artists working in Mexico City, see Clara Bargellini, "Jesuit Devotions and retablos in New Spain," in The Jesuits: Cultures, Sciences, and Arts, ed. John W. O'Malley et al. (Toronto: University of Toronto Press, 1999), 680-98, here 689. 
The research model applied in this case study of Parras can be applied to other Jesuit missions in Spanish America. At the Estancia de Santa Catalina in Córdoba, Argentina, for example, the Jesuits were involved in similarly lucrative agricultural enterprises with sugar plantations and ranching that supported the College in Córdoba. ${ }^{51}$ The historical record related to art production at Santa Catalina may shed light on how patrons were involved in painting commissions and the church decoration program. At Parras, the alliances created by the Jesuits with their donors were not the product of an isolated missionary initiative but rather an integral part of a much larger system of artistic and cultural exchange. Viewing the dynamics of art patronage on the frontier as one of many sites in a web of cultural and economic intersections demonstrates that metropolitan and frontier relationships were not opposed to one another, but rather interacted within a larger network of artistic dialogue.

$51 \quad$ Cushner, Lords of the Land, 15. 